\title{
The website for a hospital museum: the Santa Maria Nuova case study
}

\section{Niccolò Persiani*, Martina Giusti and Ilaria Elisa Vannini}

\author{
Department of Experimental and Clinic Medicine, \\ University of Florence, \\ Florence, Italy \\ E-mail: niccolo.persiani@unifi.it \\ E-mail: martina.giusti@unifi.it \\ E-mail: ilariaelisa.vannini@unifi.it \\ *Corresponding author
}

\section{Giancarlo Landini}

\author{
Department of Medical Specialist, \\ Centre Tuscany Local Health Authority, \\ Florence, Italy \\ E-mail: giancarlo.landini@uslcentro.toscana.it
}

\begin{abstract}
Museums have identified Web 2.0 as the ideal tool for the achievement of their objectives of promoting culture and involving users; indeed, it offers the conditions to allow the exchange between the interested parties. In the literature, while the use of websites by traditional museums has been extensively studied, a gap emerges with regard to the description and the use of the websites by particular museums which are hosted in working hospitals. The paper aim is to assess the prospective of a website for further the relationship and communication between the Santa Maria Nuova museum and its digital audience. The data highlighted the achievement of excellent results in terms of audience and involvement through the website, although this reality is still very young (only three years of activity) and there are ample possibilities for its digital development.
\end{abstract}

Keywords: Web 2.0; website; museum; hospital; dialogic communication; online interaction; art protection; healthcare promotion.

Reference to this paper should be made as follows: Persiani, N., Giusti, M., Vannini, I.E. and Landini, G. (2020) 'The website for a hospital museum: The Santa Maria Nuova case study', Int. J. Digital Culture and Electronic Tourism, Vol. 3, No. 1, pp.74-93.

Biographical notes: Niccolò Persiani is a Full Professor of Business Economics in School of Medicine of the University of Florence. He is the President of the Scientific Committee of the Cultural Association of the Italian Historic Hospitals. He is author of numerous publications on business economics and health management.

Martina Giusti is a Radiographer at the South East Tuscany Local Health Authority and external collaborator in research project by the Department of Experimental and Clinic Medicine of the University of Florence. 
Ilaria Elisa Vannini is a PhD Adjunct Professor of Health Economics at the School of Medicine of the University of Florence. She is a Chartered Accountant and Statuatory Auditor. Her research interests focus on planning and control systems and accounting history.

Giancarlo Landini is a Doctor of Internal Medicine in at the Santa Maria Nuova Hospital in Florence. He is the Director of the Department of Medical Specialities of the Centre Tuscany Local Health Authority and President of the Santa Maria Nuova Foundation.

\section{Introduction}

The digital revolution introduced by Web 2.0 (O'Reilly, 2005) has radically changed the way we conceive and manage communication as it has become faster and biunivocal on the internet (Crenn and Vidal, 2007). It is not addressed only to the individual but to the community of stakeholders (Waterton, 2010), who interface with the virtual representation of the reality and directly intervene on it. This has led to the widespread adoption of the website as a privileged channel by all those realities interested in maintaining close contact with their public and in increasing the sense of affiliation (Al-Lozi et al., 2012; Go et al., 2016).

Some studies underline how cultural institutions, especially museums (López et al., 2010), have adopted the website as a communication tool to develop a more interactive and collaborative dialogue with their audience (Bonaccini, 2012; Sibilio-Parri and Manetti, 2014; Cassidy et al., 2018). In particular, the benefits are obtained from the use of websites are innumerable and cover all the action areas of a museum (Orlandi et al., 2017; Tonkin et al., 2018): the enhancement of the artistic heritage through the creation of digital and interactive paths, the increasing of the stakeholder engagement and the finding of donations, not only for the protection of the possessed wealth but also for the financing of particular projects for education to beauty or respect for the common good.

From the literature review, however, there is an evident cognitive gap regarding the study of organisation, management and fruition of the website by a particular type of museums, which originated from and are located inside working hospitals and integrated into their processes.

Indeed, in Europe, old hospitals usually possess historical objects, chapels, collections of pictures, statues and ancient objects. These artistic collections are often reorganised in museum paths, surviving the healthcare activity, or have been transferred into more modern structures. However, they have sometimes remained integrated with the main activities of the hospital itself, such as in the Royal London Hospital Museum in London (Collins, 1995), the Hospital de la Santa Creu i Sant Pau in Barcelona (UNESCO site), the Scuola Grande di San Marco in Venice (Po, 2016) and many others. These examples became museums offered to the fruition of the population being part of working health institutions; here the traditional museum goals identified in ICOMS definition of $2007^{1}$ are juxtaposed with the traditional care ones.

Besides the maintenance and valorisation of the historical heritage, the major fruition of artist patrimony, the attention to accountability and the research of donors for its cultural scope, they also realise their mission by utilising own assets as instruments to 
increase the quality and quantity of care and attract donations to improve the hospital organisations.

Therefore, the aim of this paper is to evaluate the potential of a website for promoting the interaction and dialogue between the Santa Maria Nuova (SMN) museum and its virtual audience.

We have identified the SMN museum, hosted in the hospital of SMN in Florence, as the relevant case.

The study paper is structured as follows. After a brief review of the literature and a detailed description of the method used, we describe the case study, the SMN museum. Following this, the data related to the SMN Foundation website is presented; these have been obtained by extrapolating from the management software of the SMN website (Google Analytics) and from interviews carried out with staff from both the hospital and the museum. Finally, considerations and possible research development paths are drawn in the conclusion.

\section{Literature review}

The advent of the internet has led to an epochal and permanent change in the idea of communication during public relations). This digital instrument has broken down most of the space-time barriers that until then had defined the conditions for communicating. The internet offers everyone the opportunity to disseminate information instantly on a global basis, using a website as communication channel (Capriotti and Moreno, 2007; Jo and Jung, 2005; McAllister-Spooner, 2009). This contest sets the conditions for the transition from unilateral communication to dialogic communication (Kent and Taylor, 2002), today an essential presupposition for effective and strategic communication on the internet.

The desire to create dialogue between parties, who are present on the internet, led the scientist Berners-Lee to propose a 'large hypertextual database with links' to his superiors at CERN in 1990. The realisation of that database gave rise to the World Wide Web, usually known as the web. It was conceived as a global means of communication that users can use to read and write through computers connected to the internet (Berners-Lee, 1999).

The same promoters of dialogic communication have identified the web as the only possible communicative pact, which is able to satisfy the needs of all internet users. The web is the answer to the question put forward by the new communicative conditions created by the internet (Kent and Taylor, 1998). The possibility for everyone to build an individual, personalised website and the intrinsic characteristics of the web to disseminate information have led to its increasingly widespread knowledge and use.

Websites have also been identified as relevant promotional channels for immediacy, global reach and simple use (Capriotti, 2011); consequently, all those interested in promoting their purposes have begun to use them, including companies, people and institutions, not excluding the cultural ones. Of particular interest is the use of websites by museums (Hertzum, 1999).

Technological progress in the early 21 st century led to the advent of Web 2.0 (O'Reilly, 2005; Murugesan, 2007; Alexander and Levine, 2008) also known as the participative and social web. 
It refers to websites, which emphasise user-generated content, simplicity of use, participatory culture and interoperability for end users. These are important improvements compared to the first generation of the web (Web 1.0), where people were limited to viewing content in a passive manner.

Web 2.0 can be described in three parts:

1 rich internet application (RIA) - defines the experience brought from desktop to browser, whether it is 'rich' from a graphical point of view or a usability/interactivity or features point of view

2 web-oriented architecture (WOA) - defines how Web 2.0 applications expose their functionality so that other applications can leverage and integrate the functionality, providing a set of much richer applications

3 social web - defines how Web 2.0 websites tend to interact much more with the end user and make the end user an integral part of the website, either by adding his or her profile, adding comments on content, uploading new content, or adding user-generated content (e.g., personal digital photos).

If Web 1.0 revolutionised the way of conceiving communication, Web 2.0 has subverted roles (Kelly, 2010; Pulh and Mencarelli, 2015). The user becomes the active subject, while the reality which appears on the internet undergoes the action. The development of the interactions and negotiation between the parties opens the way towards fully interactive communication (Ingenhoff and Koelling, 2009; Jo and Kim, 2003).

The social dimension of Web 2.0 has as added value in its absolute ability to share any general information in any form (texts, pictures, audio, video, etc.).

All those organisations, which have entered the digital age since the time of Web 1.0, have found the maximum answer to their needs with the arrival of Web 2.0. The realised condition by Web 2.0 adapts perfectly to the needs of the user, who becomes the absolute centre around which the reality of the internet is articulated with a shift from broadcasting to ego-casting.

This applies mostly to cultural realities, especially to museums (López et al., 2010). As a result of the development of Web 2.0, museums' websites are capable of talking about the 'museum of the future' (Cunliffe et al., 2001; Jörgensen, 2004; Bertacchini and Morando, 2013; Osterman, 2018), moving from the old idea of a museum as a closed, austere place for chosen few to a museum, that functions as a bridge between past and future, both inside and outside its walls.

It has deeply revolutionised the organisational structure of museum. In fact, if before the advent of the web the preparation of art collections was aimed at making the visitor appreciate the artworks, today they are also designed to satisfy the virtual visitor (Falk, 2009; Falk and Dierking, 2013; Cassidy et al., 2018).

The sites of the museums have enhanced the knowledge of the artistic kept heritage, making it more accessible outside and more attractive through the enhanced fruition enabled the use of digital technologies, which highlight its qualities (Bakhshi and Throsby, 2012).

In museums, in addition to changing their internal organisation, Web 2.0 has created the conditions necessary to start symmetrical and interactive communication between museums with the public (Jo and Jung, 2005), which has become a cornerstone of their mission. Those interested have the best possible conditions to fully enjoy the museum's wealth (Carvalho and Matos, 2018; Hess et al., 2018) and are invited to commit 
themselves personally to the protection and enhancement of the same. We can also speak of a participatory museum (Bonaccini, 2012; Simon, 2010): the users are aware of the possibility of being jointly responsible for the achievement of the museum's objectives.

The museum and its collections may become the aggregating centre for voluntary processes based on discussion, exchange, collaboration and collective knowledge building, which is where the heart of the involvement experience resides (Bennet et al., 2016).

The involvement of users is guaranteed, in particular, through the transparency regarding the accountability mechanisms, with which reality is governed (Dainelli et al., 2013), and the museum's economic support through the provision of donations (O’Hagan, 1998).

The possibility to maximise the sharing of its mission's characteristic declination and the adherence to fixed normative constraints are particularly important for a specific kind of museum: the hospital museum.

It does not exist its definition but, from what emerges from literature review investigating the articles with this specific diction, the hospital museums are all these museums, which are situated inside working or dismissed hospitals.

These host collection of art, instruments, documents, models, etc are valorised like traditional museums to pursue the same goals, but also to arrive to other characteristic targets as:

1 the art use to support the healthcare activity (Thomson et al., 2012; Thomson and Chatterjee, 2014; Chatterjee, 2016; Lackoi et al., 2016)

2 the medical museum for the maintenance and the cure of the medical heritage and the promotion of the health (Richardson, 2002; Rainarz, 2005; Arnold and Soederqvist, 2011; Delicado, 2014; Davies et al., 2015; Zanatta and Zampieri, 2018)

3 the valorisation of the own artistic heritage to support, economically and collaboratively, the healthcare activities (Allderidge, 1992; Coleborne, 2003; Bloomfield et al., 2017; Haridas and Paull, 2017; Simpson, 2017).

The website use seems useful also in these realities; rather, its utilisation permits to better achieve not only the traditional museum objectives but also the particular ones.

In literature the use of the website was not analysed in the hospital-museum yet, although within museum institutions has been widely studied. So then the research group decided to fill the knowledge gap in this specific field of study by the website use in this precise type of museum.

\section{Method}

The case study (Yin, 2003; Eisenhardt, 1989) has been identified as the appropriate tool for conducting the research to describe the organisation and the management of the website of the kind of museum under study and to analyse the data related to its use by the public.

The Santa Maria New museum in Florence has been chosen as a representative example of a museum operating and perfectly integrated with the SMN hospital in full operation (Artusi and Patruno, 2000; Tombaccini et al., 2008). The SMN museum path is 
directly aligned with the departments of the same hospital sharing spaces, staff and timing, with close integration with hospital activities (Diana, 2010).

In 2015, the SMN museum was integrated within the ancient and innovative SMN hospital, the reference hospital unit for the emergency-urgency of the historic centre of Florence, following a studied reorganisation and exhibition of the artworks belonging to the inestimable artistic heritage of the SMN hospital.

In addition to the specific characteristic of being located in a hospital, the SMN museum is also characterised by the richness of artefacts (De Benedectis, 2002) and its location in the world's oldest hospital still operating where it was founded.

To achieve the paper's aim, in the first instance, we analyse the SMN museum, its organisation and its relationship with the SMN hospital, which is property of the Local Health Authority Toscana Centro.

Following an accurate analysis of the reality, we proceed by gathering information on the organisation and management of the SMN foundation site, which references the SMN museum. We also collect data regarding the website's use in the period from 2016 to 2019.

In December 2018, we conducted semi-structured interviews with accountants, museum referents and top management, both of the hospital and the museum, to obtain information about the management of the SMN website and the organisation behind it and the museum institution.

The semi-structured interviews used a set of five open questions for all interviewees. The prepared questions investigated the following topics:

1 description of the SMN museum and its relationship with the hospital

2 description of the SMN foundation website

3 Who manages the website's software?

4 Who manages the graphics, the organisation and the communication of the site?

5 the website's weaknesses.

Although they were not recorded, respondents' answers were immediately annotated by the interviewers.

Next, we extrapolated data about the website activity (accesses, countries of users, modalities of access, devices) from October 2018 to January 2019. This has been possible due to free access to the site's management system (Google Analytics), which regularly records the activity carried out on the site both internally and by the user. Google analytics is a web analytics service offered by Google that tracks and reports website traffic; it is used to track the website activity of the users such as session duration, pages per session, bounce rate etc. along with the information on the source of the traffic. This access was given by the service's provider. We then analysed the relationship between the pages displayed for specific museum exhibits using the obtained data.

\section{SMN hospital and its museum}

SMN Hospital was built on June 23, 1288 in accordance with the will of Folco Portinari (the father of Beatrice, to whom Dante Alighieri dedicated his poetry), who donated a plot of land to build a hospital in and for Florence. 
Located in the centre of the town, it quickly became one of the most important civil and religious institutions offering care to the population and resources for medicine studies.

Documents highlight popes, kings and nobles who visited the hospital and granted it with their protection and donations for the continuous growth of the institution, as well as the presence of numerous artists to beautify it. The porches of the hospital became the seat of the workshops of the town's most important artists (for example Ghiberti and Buontalenti). The legend tells that Leonardo da Vinci himself attended the hospital rooms for his anatomic studies.

Renewed countless times over the centuries to adapt to the needs of patients and modern healthcare, the hospital has perfectly realised a successful combination of beauty, art and healthcare. Nowadays, modern health organisation and the great architecture of the past coexist.

Among such museums, SMN probably represents one of the most interesting experiences of healthcare and museum integration. It is the most ancient hospital in the world which still stands on the same site (Landini, 2017); here, everyday, a great health organisation and a complete museum path operate at the same time and in the same place.

The investments by the Tuscan Regional administration allowed its renovation in terms of technological assets and the establishment of a structured museum itinerary which takes into account both artistic and welfare importance.

The cohabitation of social and cultural activities, modernity and the past, and technology and art has initiated a strong debate in the town and the Local Health Authority Toscana Centro regarding the best organisation and communication instruments to promote the museum pathway and improve the pursuit of both museum and healthcare objectives.

The need to maintain the rich collection of arts and the opportunity of increasing the relationship between the hospital and the population drove the management of the Local Health Authority to strengthen its autonomy in pursuing its peculiar mission.

On April 20th, 2015, a dedicate foundation (SMN Foundation Onlus) was created to care for and promote the inestimable art heritage, collected over eight centuries of the hospital's history, and to support local health projects of clinical and technical experimentation through the promotion and the exclusive governance of private donations to the hospital.

In the interviews, the management of the Local Health Authority emphasised the principal reasons behind the idea of realising a foundation separate from the health organisation, which we synthesise as follows:

1 to grant the separation between the patrimony dedicated directly to care from the historical one

2 to promote and facilitate donations and private contributions with a more identifiable subject which, due to its private and non-profit nature, could have accounting and fiscal facilitation

3 to favour better use of marketing instruments and the website for museum promotion which is separate from the institutional care communication of the local authorities. 
Nowadays, the SMN Foundation has its own budget dedicated to the museum mission as well as its own staff specialised in promotion and realisation of cultural events, donor research via cultural marketing, and advertising of its social impact. The foundation can be identified as both the museum and its offices.

Since the foundation was established, it has worked hard to promote the public fruition of the artistic collection and the knowledge of the particular declination of its museum goals, tightening a strong relationship with the city.

The realisation of its own website and the definition of a DT strategy has been the natural consequence of achieving these purposes. It helps to support the foundation's actions efficiently and effectively considering the main channels of communication.

\section{Online interaction of the SMN Foundation website}

The object of study is the site of the SMN Foundation, which contains a wide section dedicated to the museum pathway. This website was created in September 2015, about five months after the formal establishment of the SMN museum, and it is still active.

In Figure 1, we can see its organisation by the sitemap.

Figure 1 Sitemap of SMN Foundation website

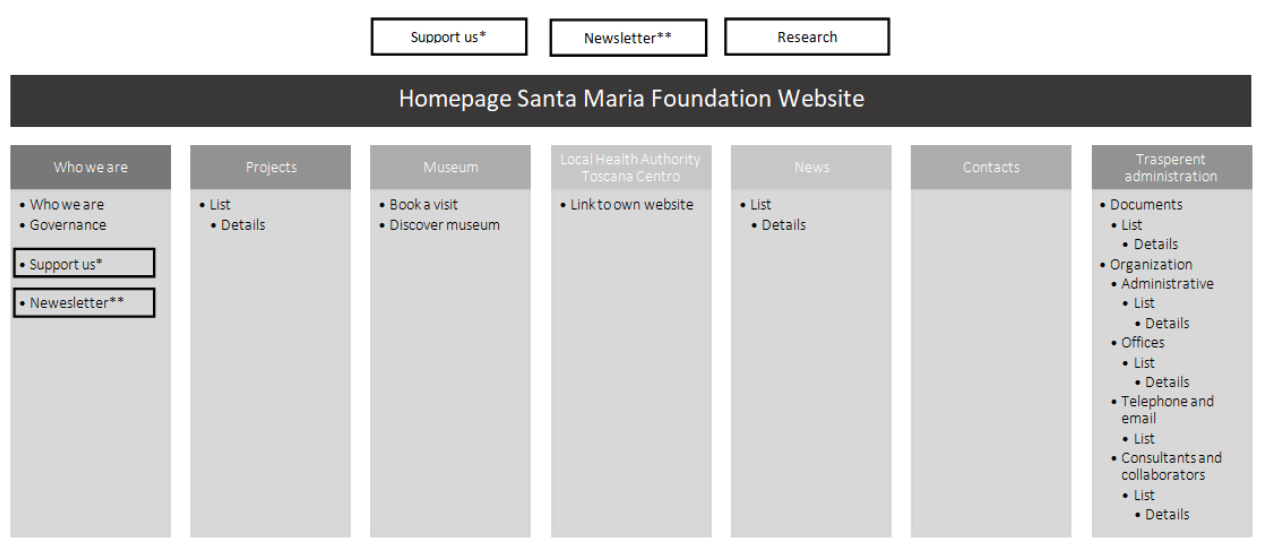

The SMN Foundation website presents a simple and schematic organisation that mainly aims at the accurate description of the reference reality and the specific objectives which it pursues.

The 'Who we are' section presents a description of the considered reality and its governance. Here, the simultaneously achievement of the following goals is particularly underlined: the protection and enhancement of artistic heritage and the promotion of health. These are the two main purposes of the museum that, although apparently are irreconcilable in a museum inside a hospital, are perfectly integrated.

Then, there are two sections entitled 'Projects' and 'News', which are dedicated to the description of initiatives and projects followed; these are aimed at supporting projects developed in collaboration with the Local Health Authority, which usually involve the 
implementation of prevention and awareness initiatives on particular health aspects or economic support for the purchase of good and health services. The site also includes the 'Local Health Authority Toscana Centro' page, which describes the Local Health Authority with a direct link to its site.

The 'Museum' section is the most interesting on the SMN Foundation website. Here, it is possible to discover the museum's itinerary and its heritage. Indeed, the wealth of the SMN museum is to be identified not only in the wonderful artistic artefacts displayed inside it (paintings, statues and tapestries), but also in the structure of the hospital itself. It is the most interactive page of the SMN website, where it is possible to book a visit, learn about the artworks or explore the interesting 'Adopt a work' proposal. With this project, the museum organisation invites interested viewers to take care of an artwork of their choosing, supporting its economic maintenance and promoting its knowledge. Through this initiative the museum received a $€ 16,000$ grant from an American foundation for the restoration of the altarpiece Madonna con Bambino e Santi by Niccolò di Tommaso and oil picture Madonna con bambino, S. Maria Maddalena e S. Caterina delle Ruote, which following the restoration will be integrated into the museum itinerary.

This is a common crowdfunding project, an informal and direct fundraising method commonly used by non-profit cultural organisations, including museums (Debra et al., 2016; Hajibayova and Latham, 2017).

It is important to note the double presence of the buttons that refer to the pages for donations and subscription to the newsletter. As found in the interviews, the museum management want to promote the declination of its social objectives in terms of health promotion, financing of health projects and purchasing of health equipment for the Local Health Authority as it is also an operating hospital. Consequently, the subscription to the newsletter is also strongly promoted as a valid channel to keep its supporters constantly updated on its initiatives.

From the interviews, it is also evident that the management of the website is responsible for the administrative staff of the museum, although it is not adequately trained in digital communication. This explains the evident lack of an effective communication strategy. Respondents pointed out that there is no design of the website's structure or of its development; updates take place only when there are special events to promote do not have a precise timing or intent.

Respondents also highlighted the need to push the SMN museum via the main social media channels because these are relevant channels for digital communication. Although there has been the will to be present on the social media since the opening of the museum, this has not been done because it requires time and capability. Furthermore, the communication of a public institution via social media is subjugated to precise rules.

Before analysing data about selected parameters of the SMN Foundation website, it is important to explain the role of conducted semi-structured interviews (Table 1). The five open questions presented investigated the internal idea, which was developed by the museum staff and the management of the Local Health Authority, of the SMN museum and the value of its relationship with the hospital.'

The responses underlined how the constitution before the SMN Foundation and, immediately afterwards, of the museum itinerary were necessary interventions for the full exploitation of a reality on which a lot has been invested, both from the Tuscany Region and from the Local Health Authority Toscana Centro itself. 
Table 1 The structure of the conducted semi-structured interview

Dear,

a University of Florence's research is trying to evaluate the potential of a website for promoting the interaction and dialogue between the Santa Maria Nuova museum and its virtual audience. The interested research group wants to gather information about this reality inside the homonymous hospital and the implementation of the website to this relative by asking you the following questions.

Immediately we thank you for your availability

\section{The researchers}

Questions

1. Can you describe the SMN museum reality and its strong link with the homonymous hospital?

2. Can you describe the structure and the organisation of the SMN website?

3. Who manages the SMN museum website's software?

4. Who manages the graphics, the organisation and the communication of the considered site?

5. What are the critical points of the SMN museum website?

Interviewing the selected sample, the feedback on the website was not positive, although it recognises that important results have been achieved in terms of use and growth of the Foundation's visibility.

From the answers, the main problem of the SMN Foundation website is the lack of planning that led to the unorganised development of the site; its navigation is difficult considering the complex structure and the use of its contents, because they are not designed for their optimal fruition through the web and, above all, mobile devices.

The management of the site is entrusted to the museum staff, who does not feel adequately prepared regarding the development of the websites and does not know the communicative logics to be adopted here. The collaborators are autonomously forming on the reported experience and try to work at its best but, given the constant increase in interest for the museum itinerary and the consequent increase in the work of setting up and managing the visits, little time remains for the care of the website and specific training for its optimisation. To date, site management consists only of the weekly update of the initiatives promoted by the SMN Foundation.

External support was requested only for the realisation and the selection of the used graphics, which is the same of the entire institution, obviously also proposed on the site.

The main problem is the lack of specific competences in the management of the website and the knowledge of the logic of dialogic communication through the websites, which is derived to the failure sharing of the adopted logic among website's programmers and SMN Foundation staff.

The only solution identified for the found the problems, seems to be a total restyling of the website and the specific training of a museum staff for the management and development of digital communication, which would no longer be limited to the website but also open up channels in the main social media. 
After the description of both the site's organisation and management and the interviews' answers, we analyse the following parameters on the SMN Foundation site:

- $\quad$ number of accesses

- $\quad$ used device

- modalities of access

- $\quad$ origin countries of users

- correlation between displayed pages and their reference to hospital-museum goals.

Each of these factors numerically represents the success of the public engagement with the SMN museum (Go et al., 2016).

During the description and analysis, we considered data for the years 2016, 2017 and 2018. We excluded the data of 2015 because it was partial, referring only to the last four months of the year.

The number of accesses indicates how many users have visited the SMN Foundation's website from 1st January 2016 to 31st December 2018 (Figure 2). These figures correspond to the online audience of the museum.

Figure 2 Number of accesses

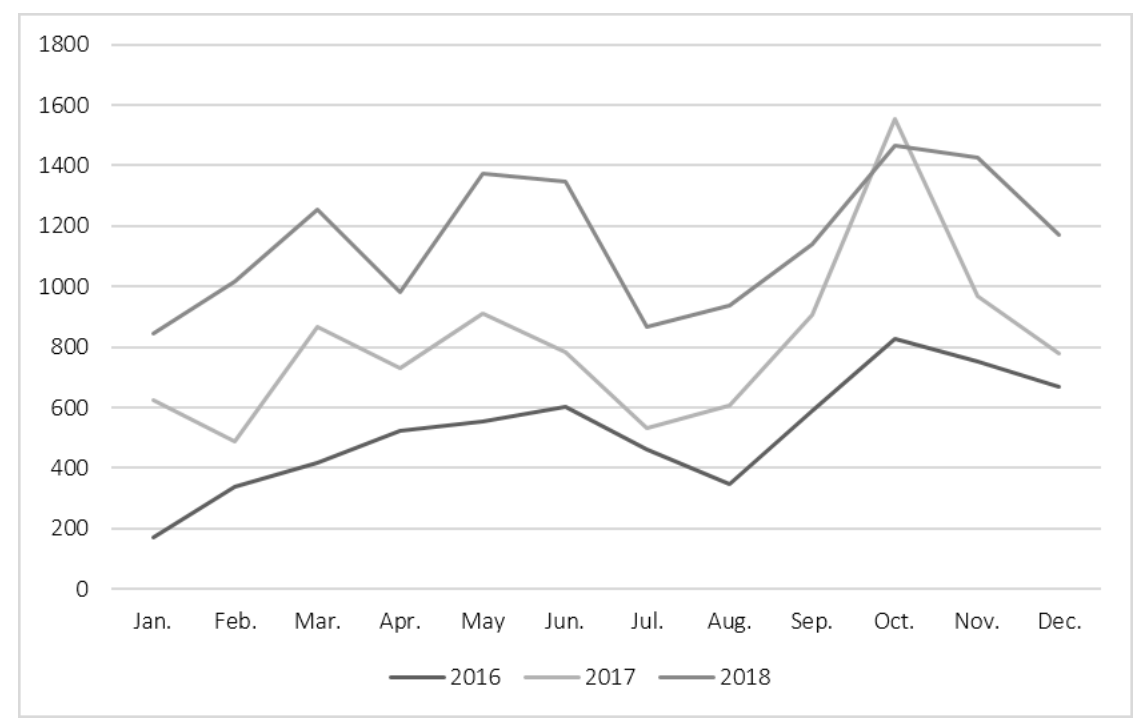

The number of accesses increased from 2016 to 2018. This demonstrates, year after year, the audience's emergent interest in the SMN museum, with accesses growing by $56 \%$ in 2017 and 42\% in 2018 compared to the previous year. Peaks are present in the months of October and November because in autumn the SMN museum usually organises specific events to favour visits and to increase fundraising. Interested tourists and donors look for information about the museum, its offers and fruition before deciding to visit or to donate. 
The following variables push to identify the most used devices by the website's visitors (Figure 3) and the modality of access to the SMN Foundation's website (Figure 4) in order to understand the most frequent methods of fruition.

Figure 3 Devices

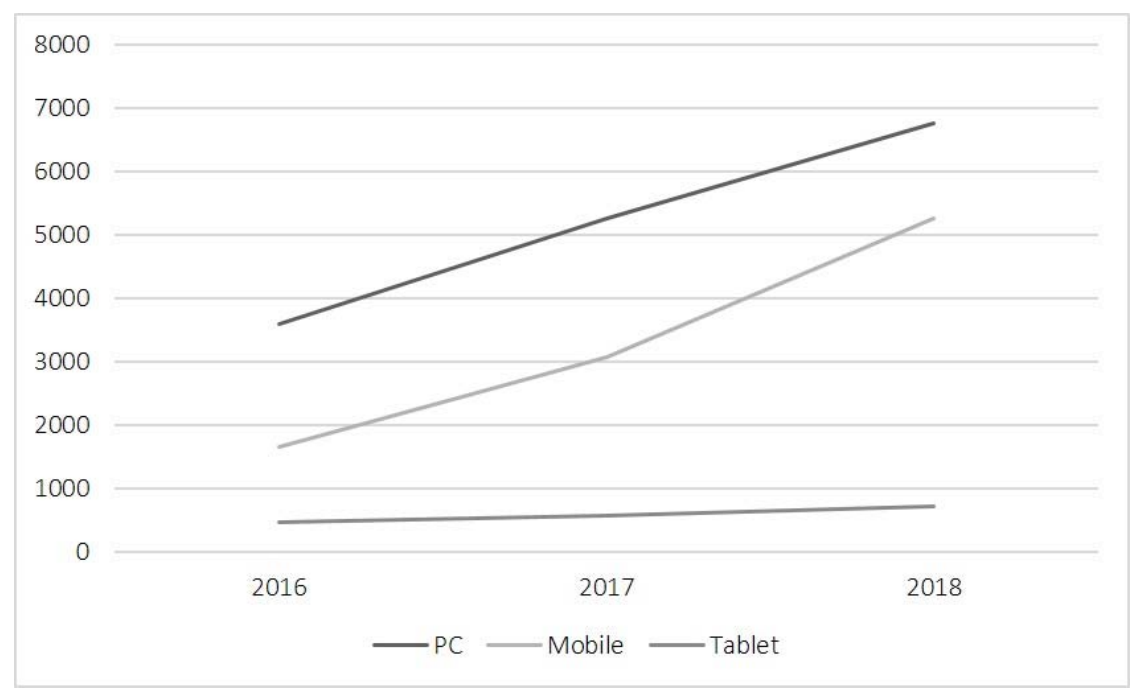

Figure 4 Modalities of access

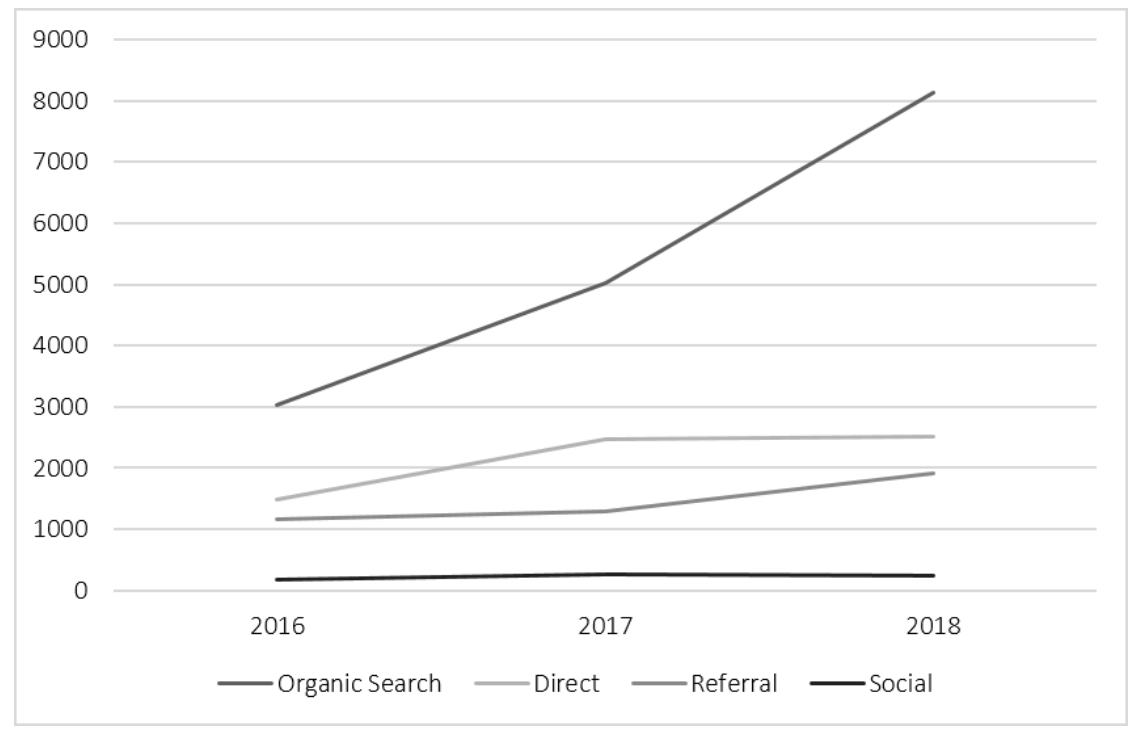

Audience visits to the SMN museum's website mostly take place through organic researches, or rather for subject, by PC. Mobile access is more frequent, while tablet viewing has been slow to take off. 
We can observe that the access by direct search of the site of the SMN Foundation and redirections from other sites are slightly increasing, while access via social networks is practically zero. In the interviews, the desire to implement the use of media in the SMN museum was also investigated. The general answer was the willingness of the administration to open official channels of the SMN museum in 2019 on the main social media platforms, in particular Facebook and Instagram, to intercept a wider audience. Social media are, in fact, considered by all respondents as fundamental, strategic and necessary channels to establish effective communication with stakeholders.

Considering the number of accesses to the site and how people reach it, the data shows that this website is still little known. It would be appropriate for the museum government to develop effective communication which is more incisive and aims at expanding the relevant public.

The data about users' origin (Table 2) shows where they come from and it enables the local audience from the foreign audience.

Table 2 Users' continents of origin

\begin{tabular}{lcccccc}
\hline & \multicolumn{2}{c}{2016} & \multicolumn{2}{c}{2017} & \multicolumn{2}{c}{2018} \\
\hline Africa & 6 & $0.1 \%$ & 8 & $0.1 \%$ & 19 & $0.1 \%$ \\
Americas & 295 & $5.2 \%$ & 585 & $6.6 \%$ & 789 & $6.2 \%$ \\
Asia & 62 & $1.1 \%$ & 215 & $2.4 \%$ & 212 & $1.7 \%$ \\
Europe & 307 & $5.4 \%$ & 394 & $4.4 \%$ & 930 & $7.3 \%$ \\
Italy & 5,024 & $87.9 \%$ & 7,552 & $85.1 \%$ & 10,750 & $84.4 \%$ \\
Oceania & 5 & $0.1 \%$ & 4 & $0.0 \%$ & 17 & $0.1 \%$ \\
(not set) & 19 & $0.3 \%$ & 112 & $1.3 \%$ & 21 & $0.2 \%$ \\
\hline
\end{tabular}

Every year, more than $84 \%$ of website's visitors come from Italy: this data is maybe the consequence of the website only being available in Italian. In the future, the possibility to select between more languages or simply the implementation of an English version could increase the number of accesses from other countries.

From the literature review, it emerged that the main reasons why traditional museums implement the use of websites are the greater dissemination of knowledge regarding the preserved artistic heritage, the involvement of users, the procurement of donations for their economic support and the full adherence to the established accountability rules. Therefore, it was decided to classify each page of the SMN Foundation's website according to these four categories in order to understand how the interest in these areas has varied during the period considered. Figure 5 shows the number of pages viewed every year for each category.

Referring to pages displayed for specific goals in 2016 and 2017, the main goal was stakeholders' involvement followed by heritage; in 2018, the main goal was primarily heritage.

It is evident how the increase of interest in the site, associated with the growing increase of contacts in years, has been dragged by the success obtained from the section concerning the museum's artistic heritage, which grew by $23 \%$ in 2017 and $45 \%$ in 2018.

The artistic heritage of the SMN museum has only been made available in the last three years after eight centuries of darkness, when it was hidden in basements of hospital and, in more recent years, situated in the rooms of the Local Health Authority as furnishing elements or displayed in unpopular and dark corridors of the hospital. 
The optimisation of its museum pathway through the website, given the great success of the artworks in possession, would surely significantly increase the number of people interested in the museum.

Figure 5 Displayed page for specific pursue

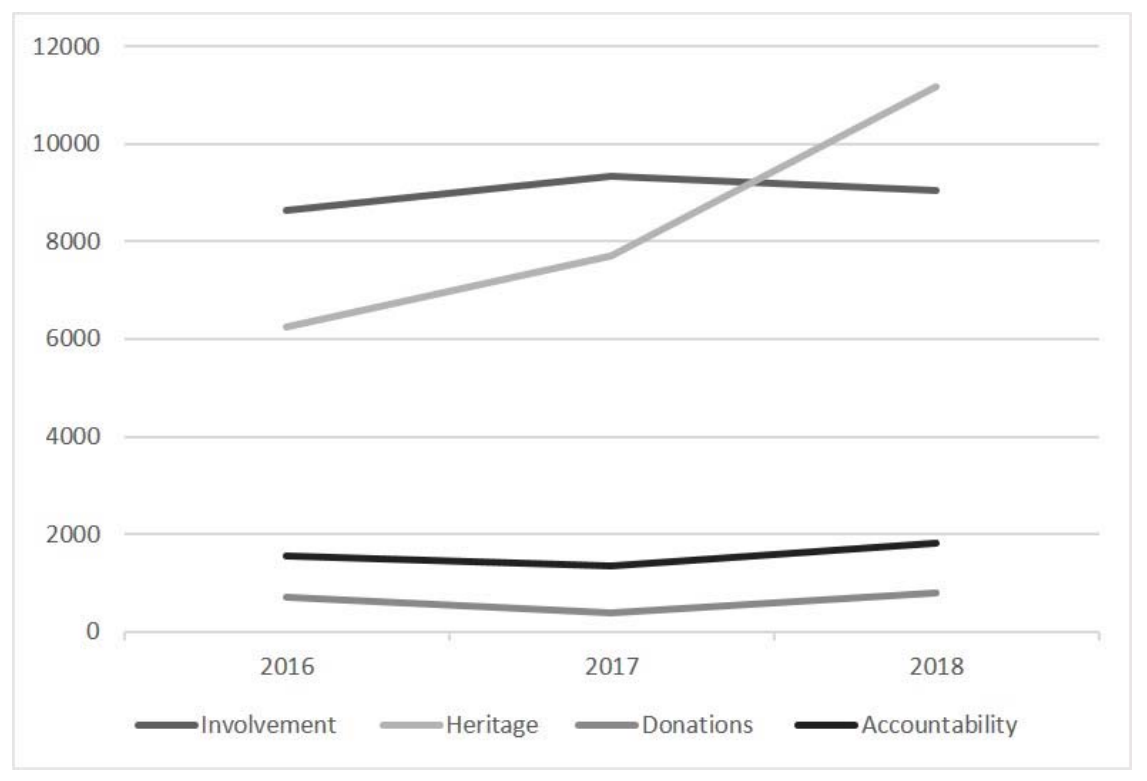

From the first year, there has also been some interest from visitors in donations, demonstrable by the contacts on the pages dedicated to them. Following a decline in 2017, this interest grew in $2018(10 \%)$. Although there is a strong orientation toward donations to the SMN museum, they have not had the desired success; perhaps it would be advisable to continue developing a more effective communication strategy for a greater diffusion of the SMN Foundation statute's fundamental principles, which are focused on social factors such as promotion of wellness, the prevention of unhealthy experience and the financing of the Local Health Authority's healthcare projects.

Finally, we can observe a constant interest in the elements of accountability presented on the website, which are a guarantee of the transparency of the organisation. Moreover, there are interesting studies that found a positive correlation between accountability and the museum's ability to attract financing (Rentschler and Potter, 1996; Dainelli et al., 2013; Carnagie and Wolnizer, 1996).

Finally, following the description of the SMN Foundation website, related to the consider museum, data concerning its fruition (number of accesses, used devices, access modalities, origins of users and evaluation of correlation between displayed pages and their reference to hospital-museum goals) have been examined.

The results stated how the SMN Foundation website has continuously increased the number of contacts with a $121 \%$ increase in accesses from 2016 to 2018 coming from 20 different countries.

Every visitor can access with different devices and all information about the museum's heritage, accountability, purposes, and initiatives for stakeholder's involvement and donations is available. 
The growth of access to the site has been driven by the increasing interest in its artistic heritage (on average 34\% between 2016 and 2018); indeed, 38\% of all accesses in 2016-2018 were visits to the heritage pages.

The pages concerning the promotion of socio-cultural initiatives and the involvement of stakeholders received constant interest, equal to $30 \%$ of the website's total views. Analysing the website, the will of the museum's administration to evidence the particular declinations of its social purposes emerged: the realisation of initiatives for healthcare promotion, which are fully-fledged goals of the SMN museum in correspondence with the principles written on the SMN Foundation statute.

\section{Conclusions}

Web 2.0 has profoundly changed digital communication, creating the conditions for the transition from unidirectional communication to dialogic communication (Kent and Taylor, 1998; 2002).

The Web 2.0 revolution has led to the maximum enhancement of websites, the pillars on which this epochal change is based. It is precisely the social dimension of Web 2.0 and its easy fruition that have characterised the website as a virtual square, where information, ideas and opinions about everything and everyone are exchanged and shared (Cunliffe et al., 2001; Jörgensen, 2004; Bertacchini and Morando, 2013; Osterman, 2018). The same is true for cultural realities, in particular for museums. The cultural sector has always required support in terms of promotion that would allow it to go outside its walls, while taking care of its cultural heritage. The website has proved to be a valid tool to help the achievement of their specific objectives because it is able to satisfy all the specific needs of this particular dimension. At the same time, it has also improved the awareness of users, making them feel co-responsible for reality itself; thus, there is full participation in the governance of the museum dimension and decision-making by its public (López et al., 2010; Pulh and Mencarelli, 2015).

We have identified the presence of particular museums which are characterised by being located in in hospital: the hospital museums. Here, museum and hospital dimensions are perfectly integrated, giving added value to each other, and the protection and the enhancement of their artistic heritage are pursued through the use of websites as a valid tool to support their activity.

In the literature, we have not found any studies that analyse the organisation, management and fruition data of the website use of this special museum; therefore, we decided to fill the informative gap with the present paper using the case study method.

The SMN museum has been identified as a valid case study because it is housed inside the working SMN hospital in the historic city centre of Florence.

Results show that:

- The implementation of the website in the hospital museum bring the same advantages as in the traditional museums, as hypothesised at the beginning of this research. In fact, the promotion of the artistic, historical and cultural heritage preserved within the hospital museum leads to a greater knowledge of the institution itself and, therefore, also of its specific social function in the healthcare sector.

- The users' involvement, to achieve the distinguished objectives of hospital museums' education and health promotion, has strong repercussions from 
organisational-managerial structure because it is necessary to collect the directions offered by the public to maintain and strengthen the relationship over time. Thus, it is important to possess professional knowledge in website managing and to develop a serious communication strategy with a linked system of monitoring and control.

Although this paper has provided important information regarding the website's use and the entailed consequences and has focused attention on a niche museum like the hospital museum, however it has limit mainly linked to the analysis of only one case. Therefore, it is appropriate to extend the survey to several hospital museums by performing a cross-case analysis, in order to highlight common factors and differences in the website's implementation and try to summarise the information about this particular type of museum.

Another study's limit has been the inability to evaluate the social media use, which today established communication channels, especially for the young. Unfortunately, the chosen case study has not yet implemented these although, as emerged in the conducted interviews, it intends to develop them.

The research group wants to deep the conducted study, overcoming its limits and developing new lines of investigation. The possible improvements to solve the identified criticalities lead to:

- $\quad$ analyse more realities to be able to compare obtained data and have an overview of the website's use in hospital museums

- $\quad$ evaluate the adoption of social media and its consequences in the considered institutions in terms of promotion, stakeholder engagement and fruition of contents.

Instead the future developments of the present study, starting from its results, are oriented to:

- $\quad$ conduct a detailed mapping of the museum pathways housed within hospitals in Europe

- $\quad$ study the growth and the evolution of this type of museum in relationship with the continuous progress in the medical field and the need to diffuse of the achieved results

- deep the methods of dissemination through social media and website of the specific health goals of hospital museums.

\section{References}

Alexander, B. and Levine, A. (2008) 'Web 2.0 storytelling. Emerge of a new genre', EDUCAUSE Review, November/December, pp.40-56.

Allderidge, P. (1992) 'The Bethlem Royal Hospital Museum', History Nurse Society Journal, Vol, 4, No. 4, pp.199-202.

Al-Lozi, E.M., Mutaz, M. and Al-Debei, M.M. (2012) 'A framework of value exchange and role playing in Web 2.0 websites', European, Mediterranean \& Middle Eastern Conference on Information Systems (EMOIS), 6-7 June 2012, Munich, Germany, pp.1-13.

Arnold, K. and Soederqvist, T. (2011) 'Medical instruments in museums. Immediate impressions and historical meanings', Isis, Vol. 102, No. 4, pp.718-729. 
Artusi, L. and Patruno, A. (2000) Gli Antichi Ospedali di Firenze: Un Viaggio Nel Tempo Alla Riscoperta Dei Luoghi D’accoglienza e DI Cura. Origine, Storia, Personaggi, Aneddoti, Editor Semper, Florence, p.396

Bakhshi, H. and Throsby, D. (2012) 'New technologies in cultural institutions: Theory, evidence and policy implications', International Journal of Cultural Policy, Vol. 18, No. 2, pp.205-222.

Bennet, R., Shaw, S. and Kottasz, R. (2016) 'Using artwork to market sensitive issues within heritage museums: Three case studies', Journal of Museum Management and Curatorship, Vol. 31, No. 5, pp.460-473.

Berners-Lee, T. (1999) Weaving the Web. The Original Design and ultimate Destiny of the World Wide Web, HarperCollins, New York.

Bertacchini, E. and Morando, F. (2013) 'The future of museums in the digital age: New models of access and use of digital collections', International Journal of Arts Management, Vol. 15, No. 2, pp.60-72.

Bloomfield, B., Cole, J. and Hahn, M. (2017) 'Carcoar Hospital Museum', Health \& History, Vol. 19, No. 2, pp.182-188.

Bonaccini, E. (2012) 'Il museo partecipativo sul web: forme di partecipazione dell'utente alla produzione culturale e alla creazione di valore culturale', Il Capitale Culturale, Studies on the Value of Cultural Heritage Journal of the Department of Cultural Heritage, Vol. V, pp.93-125, University of Macerata.

Capriotti, P. (2011) 'Communicating corporate social responsibility through the internet and social media', in O. Ihlen, J. Bartlett and S. May (Eds.): The Handbook of Communication and Corporate Social Responsibility, Wiley-Blackwell, Boston, pp.358-378.

Capriotti, P. and Moreno, A. (2007) 'Communicating corporate responsibility through corporate web sites in Spain', Corporate Communications: An International Journal, Vol. 12, No. 3, pp.221-237.

Carnagie, G.D. and Wolnizer, P.W. (1996) 'Enabling accountability in museums', Museum Management and Curatorship, Vol. 15, No. 4, pp.371-386.

Carvalho, A. and Matos, A. (2018) 'Museum professionals in a digital world: Insights from a case study in Portugal', Institutions, the Objects, the Museum and the Museum Profession, pp.48-61.

Cassidy, C.A., Fabola, A., Miller, A., Weil, K., Urbina, S., Anta, M. and Cummins, A. (2018) 'Digital pathways in community', Museum International, Vol. 70, Nos. 1-2, pp.126-139.

Chatterjee, H. (2016) 'Museums and art galleries as settings for public health interventions', in S. Clift and P.M. Camic (Eds.): Oxford Textbook of Creative Arts, Health, and Wellbeing, Oxford University Press, Oxford, pp.281-289.

Coleborne, C. (2003) 'Remembering psychiatry's past. The psychiatric collection and its display at Porirua Hospital Museum, New Zealand', Journal of Material Culture, Vol. 8, No. 1, pp.97-118.

Collins, S.M. (1995) The Royal London Hospital: A Brief History, Royal London Hospital Archives and Museum, London, 657pp.

Cunliffe, D., Kritou, E. and Tudhope, D. (2001) 'Usability evaluation for museum web sites', Museum Management and Curatorship, Vol. 19, No. 3, pp.229-252.

Dainelli, F., Manetti, G. and Sibilio, B. (2013) 'Web-based accountability practices in non-profit organizations: The case of national museums', International Society of Third Sector Research, Vol. 24, No. 3, pp.649-665.

Davies, S.R., Tybjerg, K., Whiteley, L. and Soderqvist, T. (2015) 'Co-curation as hacking: Biohackers in Copenhagen's Medical Museion', Curator, The Museum Journal, Vol. 58, No. 1, pp.117-131.

De Benedectis, C. (2002) Il Patrimonio Artistico dell'Ospedale Santa Maria Nuova di Firenze. Episodi di Committenza, Editor Polistampa, Collection Pagliai, Florence, p.296. 
Debra, A., Riley-Huff, A., Herrera, K., Ivey, S. and Harry, T. (2016) 'Crowdfunding in libraries, archives and museums', The Bottom Line, Vol. 29, No. 2, pp.67-85.

Delicado, A. (2014) 'The past and present of medical museums in Portugal', Museum History Journal, Vol. 7, No. 1, pp.18-35.

Diana, E. (2010) 'Non solo carità. L'ospedale di Santa Maria Nuova di Firenze: un risultato imprenditoriale (1285-1427)', Ricerche Storiche, Vol. XL, No. 1, pp.5-37.

Eisenhardt, K.M. (1989), 'Building theories from case study research', The Academy of Management Review, Vol. 14, No. 4, pp.532-550.

Falk, J.H. (2009) Identity and the Museum Visitor Experience, Left Coast Press, Walnut Creek, CA.

Falk, J.H. and Dierking, L.D. (2013) The Museum Experience Revisited, Left Coast Press, Walnut Creek, CA.

Go, E., Han You, K., Jung, E. and Shim, H. (2016) 'Why do we use different types of websites and assign them different levels of credibility? Structural relations among users' motives, types of websites, information credibility, and trust in the press', Computers in Human Behavior, Vol. 54, pp.231-239.

Hajibayova, L. and Latham, K.F. (2017) 'Exploring museum crowdsourcing projects through Bordieu's lens', Knowl. Org., Vol. 44, No. 7, pp.506-514.

Haridas, R.P. and Paull, J.D. (2017) 'St. John's Hospital (Morton House), Launceston, Australia: A history of the hospital and Dr William Russ Pugh's, first operations under ether', Anaesth Intensive Care. Mar, Vol. 45, No. 7, pp.29-36.

Hertzum, M. (1999) 'A review of museum websites: In search of user-centered design', Archives and Museum Informatics, Vol. 12, No. 2, pp.127-138.

Hess, M., Colson, A. and Hindmarch, J. (2018) 'Capability building and knowledge exchange of digital technologies in cultural heritage', Journal of Museum International, Vol. 70, Nos. 1-2, pp.48-63.

Ingenhoff, D. and Koelling, M. (2009) 'The potential of web sites as a relationship building tool for charitable fundraising NPOs', Public Relations Review, Vol. 35, No. 1, pp.66-73.

Jo, S. and Jung, J. (2005) 'A cross-cultural study of the world wide web and public relations', Corporate Communications: An International Journal, Vol. 10, No. 1, pp.24-40.

Jo, S. and Kim, Y. (2003) 'The effect of web characteristics on relationship building', Journal of Public Relations Research, Vol. 15, No. 3, pp.199-223.

Jörgensen, C. (2004) 'Unlocking the museum: A manifesto', Journal of the American Society for Information Science and Technology, Vol. 55, No. 5, pp.462-464.

Kelly, L. (2010) 'How Web 2.0 is changing the nature of museum work', Forum in Curator, Vol. 53, No. 4, pp.405-410.

Kent, M.L. and Taylor M. (2002) 'Toward a dialogic theory of public relations', Public Relations Review, Vol. 28, No. 1, pp.21-37.

Lackoi, K., Patsou, M., Chatterjee, H.J. et al. (2016) Museums for Health and Wellbeing, A Preliminary Report, National Alliance for Museums, Health and Wellbeing [online] https://museumsandwellbeingalliance.wordpress.com (accessed 20 April 2019).

Landini, G. (2017) Santa Maria Nuova Attraverso i Secoli, Edizioni Polistampa, Firenze.

López, X., Margapoti, I., Maragliano, R. and Bove, G. (2010) 'The presence of Web 2.0 tools on museum websites: A comparative study between England, France, Spain, Italy, and the USA', Museum Management and Curatorship, Vol. 25, No. 2, pp.235-249.

Orlandi, S.D., Calandra, C. and Ferrara G. (2017) 'Come monitorare la web strategy museale? Uno strumento concreto di ICOM Italy e MiBACT', Musei Informa, Vol. 58, p.25.

Osterman, M.D. (2018) 'Museums of the future: Embracing digital strategies, technology and accessibility', Museological Review: Museums of the Future, Vol. 22, pp.10-17. 
Pulh, M. and Mencarelli, R. (2015) 'Web 2.0: Is the museum visitor relationship being redefined?', International Journal of Arts Management, Vol. 18, No. 1, pp.43-51.

Rainarz, J. (2005) 'The age of museum medicine: the rise and fall of the medical museum at Birmingham's School of Medicine', Social History of Medicine, Vol. 18, No. 3, pp.419-437.

Rentschler, R. and Potter, B. (1996) 'Accountability versus artistic development. The case for non-profit museums and performing arts organizations', Accounting, Auditing and Accountability Journal, Vol. 9, No. 5, pp.100-113.

Richardson, R. (2002) 'From the medical museum', The Lancet, 30 March 2002, Vol. 359, No. 9312, p.1163.

Sibilio-Parri, B. and Manetti, G. (2014) 'Il dialogo fra musei e stakeholder tramite Internet: il caso delle Soprintendenze Speciali per il patrimonio storico, artistico ed etnoantropologico e per i Poli Museali', Il Capitale Culturale, Studies on the Value of Cultural Heritage, Journal of the Department of Cultural Heritage, Vol. 9, pp.123-153, University of Macerata.

Simon, N. (2010) The Participatory Museum, Museum 2.0., Santa Cruz, CA.

Simpson, D. (2017) 'Medical collecting on the frontiers of natural history: the rise and fall of Haslar Hospital Museum (1827-1855)', Journal of the History of Collections, Vol. 30, No. 2, pp.253-267.

Thomson, L.J. and Chatterjee, H.J. (2014) 'Well-being with objects: evaluating a museum object-handling intervention for older adults in healthcare settings', Journal of Applied Gerontology, Vol. 35, No. 3, pp.349-362.

Thomson, L., Ander, E., Lanceley, A., Menon, U., Noble, G. and Chatterjee, H.J. (2012) 'Quantitative evidence for wellbeing benefits from a heritage-in-health intervention with hospital patients', International Journal of Art Therapy, Vol. 17, No. 2, pp.63-79.

Tombaccini, D., Lippi, D., Lelli, F. and Rossi, C. (2008) Florence and its Hospitals: A History of Health Care and Assistance in the Florentine Area, Firenze University Press, Florence, p.150.

Tonkin, E.L., Tourte, G.J.L. and Gill, A. (2018) 'Crowd mining applied to preservation of digital cultural heritage', in Vermeeren, A., Calvi, L. and Sabiescu, A. (Eds.): Museum Experience Design. Crowds, Ecosystems and Novel Technologies, Springer Series on Cultural Computing, Chapter 6, pp.115-136.

Yin, R.K. (2003) Case Study Research, Sage, London.

Zanatta, A. and Zampieri, F. (2018) 'Origin and development of medical museum in Padua', Curator, The Museum Journal, Vol. 61, No. 3, pp.401-414.

Crenn, G. and Vidal, G. (2007) 'Les Musées Franc, ais et leurs publics a l'âge du Web 2.0. Nouveaux usages du multimédia et transfor-mations des rapports entre institutions et usagers?', International Cultural Heritage Informatics Meeting 2007: Proceedings [online] http://www.archimuse.com/ichim07/papers/crenn/crenn.html (accessed 17 April 2019).

Kent, M.L. and Taylor, M. (1998) 'Building dialogic relationships through the World Wide Web', Public Relations Review, Vol. 24, No. 3, pp.321-334.

McAllister-Spooner, S. (2009) 'Fulfilling the dialogic promise: a ten-year reflective survey on dialogic Internet principles', Public Relations Review, Vol. 35, pp.320-322.

Murugesan, S. (2007) 'Understanding Web 2.0', IT Pro, July-August, pp.34-41.

O'Hagan, J. (1998) 'Art museums: collections, deaccessioning and donations', Journal of Cultural Economics, Vol. 22, Nos. 2-3, pp.197-207.

O'Reilly, T. (2005) What Is Web 2.0. Design Patterns and Business Models for the Next Generation of Software, 30 September [online] http:// oreilly.com/web2/archive/what-is-web20.html (accessed 25 Mai 2005).

O'Reilly, T. (2007) 'What is Web 2.0: design patterns and business models for the next generation of software', Communications \& Strategies, No. 1, p.17 [online] http://ssrn.com/abstract_1008839 (accessed 15 May 2019). 
Po, M. (2016) La Scuola Grande di San Marco a Venezia, Editor Panini, Mirabili visioni collection, EAN:9788857011332.

Waterton, E. (2010) 'The advent of digital technologies and the idea of community', Museum Management and Curatorship, Vol. 25, No. 1, pp.5-11.

\section{Notes}

1 ICOM (International Council of Museums by UNESCO) museum definition (2007): "Permanent institution in the service of society and its development, open to the public, which acquires, conserves, researches communicates and exhibits the tangible and intangible heritage of humanity and its environment for the purposes of education, study and enjoyment." 